https://helda.helsinki.fi

\title{
The start-up state: Governing urbanised capitalism
}

\section{Moisio, Sami}

2020

Moisio , S \& Rossi , U 2020 , ' The start-up state: Governing urbanised capitalism ' ,

Environment and Planning A, vol. 52 , no. 3 , ARTN 0308518X19879168 , pp. 532-552 . https://doi.org/10.1177/030

http://hdl.handle.net/10138/319796

https://doi.org/10.1177/0308518X19879168

unspecified

acceptedVersion

Downloaded from Helda, University of Helsinki institutional repository.

This is an electronic reprint of the original article.

This reprint may differ from the original in pagination and typographic detail.

Please cite the original version. 


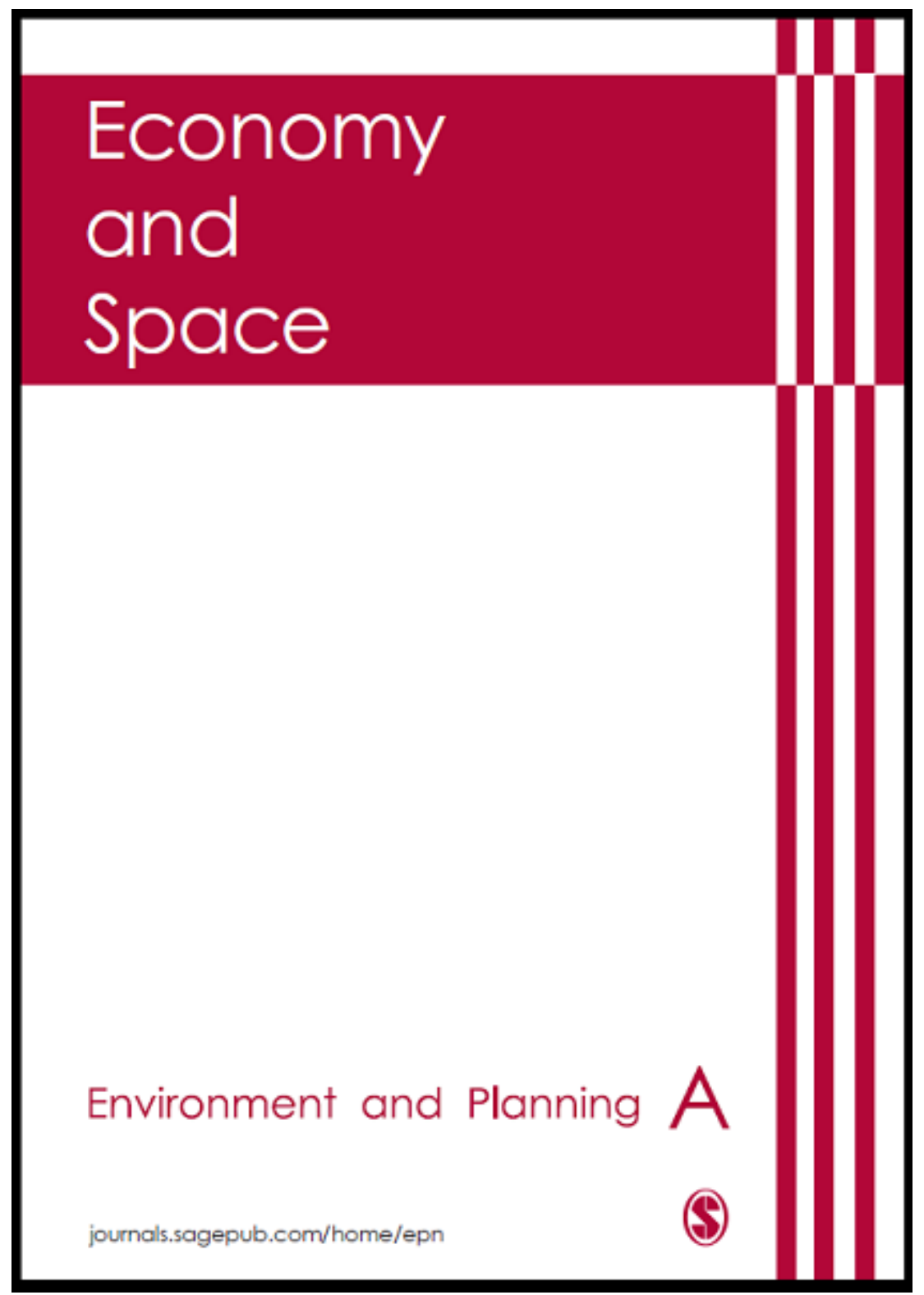

\section{The start-up state: Governing urbanized capitalism}

\begin{tabular}{|r|l|}
\hline Journal: & EPA: Economy and Space \\
\hline Manuscript ID & EPA-2019-0048.R1 \\
\hline Manuscript Type: & Theme issue article \\
\hline Keywords: & $\begin{array}{l}\text { The state, start-up economy, entrepreneurialization, start-up city, } \\
\text { strategic urbanization of the state }\end{array}$ \\
\hline
\end{tabular}




\section{The start-up state: Governing urbanized capitalism}

This paper assesses through a comparative lens the mutating role of the state in today's flourishing of technology hubs in major cities and metropolitan areas across the globe. Conventional wisdom associates the contemporary phenomenon of high-tech urbanism with minimum state intervention. In public as well as in scholarly debates, technology-intensive urban economies are customarily portrayed as a phenomenon whose formative creativity and ethos stems from an essentially postpolitical nature. As these economies emerge thanks to the cooperative dynamism of urban societies, political governments are considered merely as coordinators of inter-actor relationships, particularly as managers or orchestrators of innovative 'business ecosystems' and 'platforms'. We, in turn, suggest that today's emergence of technology-based economies in a selected circle of major cities and metropolitan areas is an inherently political phenomenon, as it is closely linked to what we call the strategic urbanization of the state. Looking at the trajectories of Finland and Italy during the postrecession decade of the 2010 s, we disclose the state-driven selective mobilization of urban economies as a response to the low-growth present of national political economies. In doing so, we argue that the entrepreneurialization of selected urban locations cannot be understood without considering the qualitatively transformed roles of the local and national states. The coming together of entrepreneurialist and urbanizing state strategies disclose a shift towards a start-up state whose distinctive features differ qualitatively from those of both the investment-oriented late-Keynesian entrepreneurial state and the decentralized local economic governance envisaged by today's cityinnovation theorists.

\section{Introduction}

The crisis of economic and political rationality that has followed in the wake of the recession of 2008 has led a growing number of pundits, scholars and political actors to invoke a return to the nationstate in response to the failures of market-led globalization. At the same time, other commentators 
have reacted to the new scenario by advocating a more decidedly decentralized, post-political management of local economies. As post-recession capitalist economies have come to be dominated by a new generation of high-tech corporations and start-ups that have increasingly urbanized capitalism, scholarly and public debates have particularly concentrated on the management of this novel configuration of global capitalism. Two approaches have particularly emerged: a neoKeynesian proposal for a 'neo-entrepreneurial state', drawing on the lessons of the past decades of state-driven innovation policies, and a neo-Jacobsian perspective (inspired by the work of urbanist Jane Jacobs) on self-organized economic governance reflecting the endogenous potential of urban ecosystems.

On the one hand, the scholars and pundits who have embraced a neo-Keynesian position reassert a more proactive role for the state in the economy through an expansionary fiscal policy entailing greater investment in technology and infrastructure. In particular, Mariana Mazzucato (2013) has distinguished herself within public debates by putting forward the influential notion of the 'entrepreneurial state', which emphasizes the vital contribution that public policy made with technology investment since the late 1980s in highly innovative regions and sectors such as Silicon Valley and the biotechnology industry in the United States. Through this concept, Mazzucato challenges dominant political narratives on the advent of a knowledge-intensive "economy of innovations". In such a dominant view, "business is accepted as the innovative force, while the State is cast as the inertial one - necessary for the 'basics', but too large and heavy to be the dynamic engine" (Ibid.: 1).

Mazzucato (2013) demonstrates that the entrepreneurial state is a key player in the value creation mechanism; it creates value in the economy rather than merely interferes firms in their attempts to generate value. Put briefly, the entrepreneurial state creates economic value through government interventions. In addition, the entrepreneurial state has not only acted as a direct value creator, but also played a key role as an investor. Mazzucato (2013) highlights that the state has funded both basic and applied research that have contributed enormously to bringing about some of 
the well-known knowledge-intensive commercialized products ranging from smartphones to pharmaceutical products. Indeed, the state has not only taken the role of an investor, but it has also taken the role of a high-risk-taking venture capitalist: the state has played a greater role than the private venture capital funds in investing in vulnerable early-stage firms - many of which fail and disappear (Ibid. 47-49).

In parallel with Mazzucato's (2013) neo-Keynesian perspective, there is a growing body of neo-Jacobsian scholarship that emphasizes the endogenous dynamics of urban environments, leading the city to act as an 'innovation machine' (Florida et. al. 2017), thanks to the unique condensation of human and creative capital in the economically thriving urban agglomerations and metropolitan areas (Florida, 2012; Glaeser, 2011; Moretti, 2013). Influential urban economists such as Edward Glaeser, Richard Florida and Enrico Moretti who have become popular amongst policy makers and the mass media - for this reason labelled as 'celebrity urbanologists' by their critics (Peck, 2016; McNeill, 2017) - have thus highlighted the intrinsic virtues of urbanism in contemporary knowledge-intensive societies. Despite the internal differences of their arguments, a common trait in today's "Western urbanology" (Rossi, 2019) is the idea - derived from Jane Jacobs (1969) - of scope and diversity as the main explanation for today's urban flourishing of technology-intensive capitalism.

Contrary to Mazzucato (2013) and the other advocates of a neo-Keynesian entrepreneurial state, the abovementioned Western urbanologists question the value of direct government intervention. In their view, the renewed urban centrality in public policy has to be taken as an opportunity for empowering local leadership and treating local economic governance in a truly systemic, decentralised manner, offering at the same time fiscal incentives capable of turning what Florida terms "the clustering force" of today's urbanism into an advantage for all (Florida, 2017). In this perspective, the city is understood as a complex ecosystem composed of a variety of economic activities and market platforms. Governing this complexity, therefore, is conceived primarily as 'a management problem', involving the selection of 'the appropriate organizational structure for tackling the issues at hand" (Visnjic et al., 2016). 
In this paper, we argue that actually existing high-tech start-up economies depart from both the statist, neo-Keynesian and the neo-Jacobsian, post-political models of economic governance. We go on to argue that, beyond any normative model, a start-up economy becomes constituted through the intersection of socio-spatially and historically situated entrepreneurializing, urbanizing and technologizing imaginaries, practices and strategies. In our perspective, the start-up economy is not a clearly delineated hegemonic project in Gramscian terms (Jessop, 1990). We rather conceptualize it as an ideologically intricate neoliberal project, namely a historically contingent process in postrecession "cognitive capitalism" (Moulier Boutang, 2011) that brings together people, government, firms, technologies, organizations and governmental technologies in the name of economic growth, development and national success.

Through developing the concept of the start-up state, we seek to shed new light on how the contemporary process of knowledge-based economization takes hybrid forms, going beyond the government-governance binary. In particular, our research exposes how the emergence of the startup economy can be conceptualized as a form of strategic urbanization of the state (hereafter referring to the so-called nation-state), in which the state seeks to capitalize on the endogenous entrepreneurial capacity of urban environments. While start-up economies are ubiquitously spread across the globe (in both the Southern and Northern hemispheres), the strategic urbanization of the state appears to be a geographically selective as well as variegated process that requires attention to the specificities of the socio-spatial and historical contexts.

We seek to shed new light on the rise of a political-cultural-economic formation that we term the start-up state through analysis of the recent developments in Finland and Italy. These states were hard-hit by the recession of the late 2000s and the early 2010s. Whereas the analysis on Finland demonstrates the coming together of entrepreneurialization and urbanization in state strategies, the Italian case highlights more explicitly the state-orchestrated production of urban champions as innovation hubs, particularly that of Milan. 
Our paper proceeds through four sections. In section two, we discuss the ways in which the role of the state has been overshadowed in the scholarly debates on start-up economy. Drawing on our empirical research, section three comparatively examines how the state has had a constitutive role in the production of start-up economic forms in Finland and Italy. In the final section of the paper, we bring together various dimensions of the start-up state.

\section{Debunking the state in urban-centred imaginaries of the start-up economy}

Knowledge-based economization refers to a historically contingent geopolitical process that produces territories of wealth, power and belonging (Moisio, 2018b). Specific political forces seek to build an economic form based on innovations, selective state spaces, and particular segments of the populace (Jessop, 1990). This process is strategic in a dual sense. First, it is strategic in the sense of facilitating the circulation and accumulation of capital in the contemporary historical conjuncture through the creation of spaces that allow the generation of surpluses and extraction of value. Knowledge-based economization hence produces cycles of territorial transformation that inescapably involve crucial issues such as the relationships between states and cities.

Second, the process of knowledge-based economization is strategic in the sense of producing competitive forms of life that can be harnessed both to the circulation and accumulation of capital, and to the maintenance of the territorial state. In sum, knowledge-based economization is both spatializing and subjectivating: it brings together governing space and populace.

It has become all too evident that urban space acts a magnet for venture-capital flows (Florida and King, 2018) thanks to its functioning as an 'ecosystem' that brings together knowledge, creativity and a variety of communities of practice (Rossi and Di Bella, 2017). Urban environments thus enable the individual to leverage her human capital as an 'entrepreneur of herself'. As the widespread usage of the term ecosystem signals, the process of knowledge-based economization has shifted qualitatively over the past decades, in both economic and spatial terms. It emerged in the form of Keynesian technopolization in the late 1980s (Castells and Hall, 1994), and manifested itself in 
imaginaries and practices that were increasingly predicated on the idea of the 'smart city' from the late 1990s onwards (Mahizhnan, 1999).

In today's economic development imaginaries, as well as in business consultancy and policymaking more broadly, entire cities take the form of state-orchestrated platforms for experimental governance and creative business activity. The increasingly intimate connection between the urban, the capitalist extraction of value, and entrepreneurial forms of life is certainly a defining feature of the latest round of knowledge-based economization. The capability of the new start-up entrepreneurs to commodify digital formats and contents - a kind of copyright economy based on the Internet - as successful businesses, and the associated shift from 'mere technology' to 'content' is thus almost invariably associated with the urban. In such a view, the new, economically profitable ideas arise from a cooperative and culturally and socially rich urban fabric. In these urbanophile imaginaries, lively urban environments are said to contribute fundamentally to the production of a new generation of innovative entrepreneurs, essential to the operation of the knowledge-intensive form of capitalism (cf. Scott, 2014). The capitalist extraction of value from urban environments, therefore, entails a relentless invention of entrepreneurial forms of life drawing on daily practices of cooperation in the metropolis understood as a "social factory" (Negri, 2018). This dynamic represents a remarkable shift from both the Fordist and immediately post-Fordist management of urban economies, when the capitalist valorization of urban settings targeted conditions of obsolescence and devalued property in the built environment (Weber, 2002). In those contexts, state intervention was intended to provide assistance to private investors through urban-renewal programmes as well as, more recently, through fiscal enclaves such as Business Improvement Districts and special economic zones. Those fiscal expansionary policies (relying either on public expenditure or tax cuts) allowed the state to impose its sovereign prerogatives through situational procedures and norms granting entrepreneurial freedom to foreign and domestic investors (Ong, 2006).

While those interventions were and still are illustrative of the neoliberal recourse to exception as a fundamental principle of sovereign rule, start-up economies are customarily constructed upon 
the normalcy of city life. In these economies, the urban is addressed not as an empty space to be recolonized by rapacious investors, but as a socially rich and economically productive space within which the potential of life can be harnessed to economic purposes. As production is seen to take place in social relationships within the context of knowledge-intensive capitalism, the generation of relational subjectivity becomes vital, not just the possession of knowledge per se (Read, 2009). Here, the urban marks a social space in which skilled start-up entrepreneurs become involved in collaborative activities related to co-creation, co-option and enriching interaction, to name but a few, and produce economic value both through and in these interactions.

The real, dense entrepreneurial city "is made of flesh, not concrete" (Glaeser, cit. in Smith, 2012), as one "celebrity urbanologists" (Peck, 2016) revealingly puts it. In such an economic imaginary, "urban density provides the clearest path from poverty to prosperity" (Glaeser, 2012: 1). The dense urban spaces are desirable, for they enable face-to-face interaction of people who cherish the sociability of a city and love new ideas that have economic potential. According to Glaeser (cit. in Jenkins, 2015), "what globalization and new technologies do is radically increase the returns to being smart. We are a social species that gets smarter by being around other smart people, and that's why cities thrive".

Start-up economic imaginaries are predicated on a seamless connection between work in urban space and outside-work urban life, thus making the border between working time and nonworking time largely obsolete. Its protagonists are aspiring happy-city entrepreneurs who mix ideas of common good, collaboration and sharing with value creation (Glaeser, 2011; Cohen and Muñoz, 2016). In this capacity, the imaginaries of the start-up economy bring together and meld the risk-taking economic subject with an urban communitarian figure who is inspired by an ethos of 'sharing'.

With regard to generating value, the start-up economy blurs the boundaries between the workplace and the place of living, and produces a particular segment of the population as the economic-political ideal. More importantly, their capacities and ethics are articulated as if the start- 
up subjects resided in the affective micro-fabrics of the urban. In other words, the urban is understood as if it brought them pleasure both at work and outside of it - reconnecting the spheres of production, social reproduction and leisure. In the imaginaries of the start-up economy, the constitution and maintenance of labour power is thus ultimately an urban affair.

The conceivably flexible subjects of such economization are the office in itself. The urban fabric, in turn, is understood by the start-up economy boosters in particular as providing the necessary backdrop to re-work the ways in which the start-up populace understand their role as 'constant innovators' for whom the boundary between work and non-work is becoming increasingly uncertain. It is for this reason that intensive urban space, in all its qualitative aspects, appears in the imaginaries of the start-up economy as a crucial constitutive element.

The abovementioned start-up imaginaries, premised on ideas of urban density and social cooperation in 'happy cities' (Montgomery, 2013), operate in tandem with an imaginary that contrasts with dysfunctional statist nationalism, purportedly rigid party politics, clientelism, and seemingly functional and de-statist cities (see e.g. Barber, 2013). In so doing, the latter imaginary combines economic productivity with the idea of a new de-statist urban age.

In the start-up economy imaginaries, the urban appears as a vast open-plan office, a truly postpolitical laboratory for social interaction, a community-making platform, or a test-bed in which the creativity of entrepreneurs is not restrained by old capitalists and state bureaucracy. The urban is thus built into the start-up economic imaginaries with a strong libertarian tone, but the appeal of the startup city across political parties stems also from its seemingly apolitical and de-statist nature. In the academic literature, too, the start-up economy is often articulated as if it were less statist than the lateKeynesian forms of knowledge-based economization. In such a view, the technopoles of the 1980s and the 1990 s are 'more' state-orchestrated or statist in nature than the recent start-up urban economies (Bunnell, 2002).

It does not come as a revelation, therefore, that the conventional wisdom tends to portray startup economies in the technology sector as distinctively urban-centred phenomena. So far, academic 
scholarship - albeit still scarce and embryonic on this topic - has substantially seconded this idea (Florida and Mellander, 2016; Florida and King, 2018), while critical scholars have only expressed reservations about the overlooked role of public policy (McNeill, 2016; Rossi and Di Bella, 2017). Overall, existing scholarship has left issues such as state regulative practices, state restructuring, state bureaucracy and policy-making largely unexplored, providing an understanding of the urban as an entity somehow spontaneously generating high-tech entrepreneurship and economic value. Citycentric conceptions of the start-up economy have emerged in conjunction with a rapidly expanding knowledge industry, which tailors all sorts of start-up city rankings, mappings and indices. These rankings produce cities discursively as actually existing start-up 'ecosystems' and economic territories that are involved in a purportedly fierce global inter-spatial competition (Moisio, 2018b).

As we have noted above, the constitutive ideas of start-up economy are often comprehended as arising from a cooperative and culturally and socially rich urban fabric rather than from the governmental processes of the territorial state. However, as Dierwechter (2018) has argued, the role of the state in politically reconstructing an ideal of the good society has returned to prominence in the seemingly post-political contemporary context, characterized by the 'animating fantasies' (Dean, 2009) of smartness, creativity, ecosystemic innovation and competitiveness. In a similar vein, we believe that it is analytically problematic to conceptualize the start-up economy as a merely postnational, de-statist, city-centric and firm-based economic world. Certainly, the late-Keynesian economic interventions of the state differ from the recent economic interventions of the state. Neither do we deny the role of cities as "self-promoting islands of entrepreneurship" (Amin and Malmberg, 1992: 413) or as effective "ecosystems" within which firms with a "symbolic knowledge base" (Asheim et al., 2007) are nurtured and developed. However, we make an analytic distinction between 1) the urban as a geographical source of economic-value creation, providing fertile ground for startup economies and other innovative activities; and 2) the new socio-spatial dialectic - what we characterize as the cross-fertilization between the state-orchestrated entrepreneurialization of the 
urban and the urbanization of the nation-state - behind today's urban centrality in the global economy, or what we call "urbanized capitalism".

In the ensuing pages, we seek to demonstrate that the state occupies a crucial role in developing cities as selective spaces of start-up entrepreneurialism. We suggest, rather, that the constitution of the start-up economy signals a state-driven mobilization of the urban, and the introjection of the urban imaginary into state apparatuses at the same time. Drawing on a wide range of empirical sources, including official documentation, newspaper articles, long-term observation and in-depth interviews with qualified informants, the next section of this article will offer illustration of the EU politico-economic context through a comparative analysis of the distinctive role played by national governments in the invention of urbanized start-up economies in Finland and Italy.

\section{The state-driven mobilization of the urban: lessons from Finland and Italy}

In both the Finnish and Italian contexts, the idea of start-up economies as engines of national innovation strategies has gained currency during the post-recession years of the early 2010 s, in times characterized by the harsh realities of fiscal austerity as well as by a spasmodic search for novel growth- and future-oriented rationales. The societal imaginaries of this state-driven project, therefore, have emanated from an effort to re-construct, nurture, facilitate, govern and expand the start-up economy as a kind of national strategy for rescue and rebirth in the years that have followed the 'great recession' of the late 2000s and the early 2010s. Despite their obvious differences (starting with demographic size, Italy being more than ten times bigger), Finland and Italy experienced the 'great recession' in strikingly similar ways, as the economic slowdown of the late 2000s impacted their national political economies heavily after years of relatively steady growth. Moreover, both countries had experienced in severe ways the economic recession of the early 1990s (a recession that hit a limited number of countries in Europe) and both countries had entered the Eurozone in the mid-1990s after painful economic adjustments. 
In 2009, after about 15 years of almost constant growth and relative optimism, the economies in these two countries took an exceptional tumble, as GPD growth rates decreased by $8,3 \%$ in Finland and 5,5\% in Italy. Over these same years, these economies witnessed a precipitous decline of the ICT sector, particularly of the so-called 'new media' industries that had emerged during the first Internet era in the second half of the 1990s. In previous years, within literature dealing with information technology, Finland was made famous as the so-called 'Finnish model', combining technology-led economic development with the preservation of a robust welfare state, which complemented more established models in this sector such as those of Singapore and Silicon Valley (Castells and Himanen, 2002; Dahlman et al., 2006). For its part, within debates over post-Fordist economies, Italy had long been associated (particularly from the mid-1980s onwards) with endogenous economic development, known as the 'Third Italy' model (Storper, 1997). The crisis that became evident in 2008 shattered previous illusions that these countries had successfully managed to set aside their long-term structural weaknesses.

As a consequence, since 2010, national governments in both countries have committed to an economic policy aiming to bring together fiscal austerity and the pursuit of GDP growth. In Italy, in 2011 a technocratic government led by a former EU commissioner and professional economist, Mario Monti, replaced the Berlusconi cabinet without elections, with the explicit mandate of undertaking the 'structural reforms' requested by the EU. The philosophy of the Monti government centred on the notion of 'expansionary austerity', an idea that became dominant within mainstream economic thinking in the European Union during the post-recession phase of the early 2010s; an apparent oxymoron postulating growth effects deriving from systematic budget cutbacks (Blyth, 2013).

As its reputation became closely associated with the public spending cutbacks and the unpopular pension reform contained in the so-called 'Rescue Italy Decree' (or Decreto Salva Italia), the technocratic government started to pursue an explicitly pro-growth agenda based on the catchwords of technological innovation and global competitiveness. The approval of the so-called 'Growth 2.0 Decree' was the culmination of this pro-growth strategy. The provision of financial 
incentives for innovative start-ups - and their legal recognition - was central in this strategy, along with the simplification of bureaucratic procedures for setting up a new enterprise. The vision behind the 'Growth 2.0 Decree' was outlined in a report published by a task force of the Ministry for Economic Development entitled in an evocative manner "Restart, Italia!" (Ministero dello Sviluppo Economico, 2012). A specific section was dedicated to the geographical dissemination of businessincubation initiatives, identifying so-called 'startup-friendly territories' capable of giving rise to 'innovation-oriented ecosystems'. According to the report, the combination of competition with collaboration is key to the pursuit of this goal: "we build on the assumption that the winners of interspatial competition[s] are those that are able to organize collaborative relations locally" (Ibid.: 121).

Following the general elections of 2013, a new government led by Matteo Renzi - a young politician drawing inspiration from Tony Blair and his post-ideological 'Third Way' project continued to emphasize support for digital innovation and start-ups as a key pro-growth policy balancing the austerity measures persistently requested by the European Commission. Renzi's first public appearance as head of the Italian government was at H-Farm, a start-up accelerator in Treviso, in the Veneto region, a fast-growing economy in Northeast Italy (and historically a key manufacturing centre in the 'Third Italy'). In March 2015, Renzi's government approved the 'Investment Compact', a law that extended the 'start-up model' of business management to all innovative small firms.

However, Renzi's subsequent designation of Milan as a 'model city' for the entire national political economy was even more significant (especially at the level of public discourse) than nationwide industrial policies. In 2015, Milan hosted the Expo fair titled "Feeding the Planet, Energy for Life", which celebrated the potential for economic growth offered by the combination of food, health, technology and culture. The Expo proved to be a highly successful event that reasserted Milan's international reputation as a city "exciting to inhabit, a place to consume as well as produce, and that is another road to urban success" (Glaeser, 2011, 238). In a speech given in September 2016, during a ceremony in which the national government announced a special funding scheme for Milan's 
urban innovation projects, Renzi stated: "Milan has to take Italy's hands and show the way forward out of a challenging situation affecting our country at the economic level" (Mancini, 2016; author's translation).

The Finnish experience with the politics of austerity and related structural reforms resonates with the Italian case. In Finland, an almost naturalized set of economic-political arguments has resulted from the struggle over dominant knowledge-formations of national economy since the deep recession in the early 1990s. The recession in the early 1990s created a space for structural reforms that were predicated on variants of the New Public Management, slowing down public spending, irrespective of the economic situation (Ahlqvist and Moisio, 2014). These reforms continued throughout the 1990s with 'rainbow governments' that brought together the political left and right.

The global financial meltdown of 2008 , coupled with the gradually worsening domestic economic situation from 2009 onwards in particular, has generated fertile ground for the expansion of austerity measures in Finland. The result of the crisis talk and many forms of prescriptive crisis analysis was that austerity measures were increasingly presented as a kind of unavoidable standard practice of the Western state (Moisio and Paasi, 2013). Austerity measures have been gradually put in place by technocratic governments as if they represented morally high-profile politics "of getting difficult things done". Indeed, campaigns for the national elections both in 2011 and especially in 2015 were dominated by reasoning which reverberates with the central tenets of austerity-driven policy 'reforms'. The negotiations to establish a new conservative center-right government for the years 2015-2019 were based on a wide-ranging consensus among the three parties that formed the cabinet on the elementary need to kickstart growth by cutting public spending, tackling price competitiveness and public-sector deficiencies by freezing wages, launching new entrepreneurial agendas and introducing policy experimentation. These negotiations were based on an idea that the difficulties faced by the Finnish national economy are not only based on business cycles but are deeply structural in nature, touching on productivity and innovativeness in both private and public 
sectors. Moreover, the lack of small and middle-size companies capable of attracting foreign capital was recognized as one of the key "national problems".

Like Italy, the consecutive two governments elected during the post-2008 recession years have placed high hopes on innovation-based policies of growth in kick-starting the national economy. This is not surprising given that since the 1990s the gradual neoliberalization of Finland has been characteristically a technocratic process whereby technological knowledge, and the whole technoindustrial complex, has assumed a pivotal role (Ahlqvist and Moisio, 2014). Indeed, the government programmes of 2011 and 2015 are premised on the idea of constructing a new state that would embrace technology-intensive development and productivity across different social spheres. In 2011, the Prime Minister Jyrki Katainen's programme (centre-right National Coalition Party and the Social Democratic Party as the leading groupings) depended on the idea of building a link between entrepreneurship, education and innovation. The latter, a highly technocratic government consisting of the centre-right Centre Party, the National Coalition and the national revanchist Finns Party, made a pervasive connection between the culture of entrepreneurship, national innovation capacity, policy experimentation and education as central means to foster national competitiveness and economic growth. The following quotes from the government programmes and implementation plans in 2011 and 2015 reveal a great deal of the dominant political rationality during the post-2008 recession years in Finland:

Links between education and the working life, and employee and entrepreneurship education providing information about the rights and obligations of citizens, employees and entrepreneurs will be enhanced at all levels of education ... Efforts will be made to increase interest in and preparedness for entrepreneurship by means of training at various levels of education. (Programme of the Jyrki Katainen Government of Finland 2011: 65) 
Expertise is not being converted into innovations, innovations are not commercialized. We are losing our expertise-based competitive edge. We must set people's resources free to engage in creative activity, entrepreneurship and the creation of wellbeing. Finland must become a society founded on know-how, entrepreneurship, equality and caring. (Programme of the Juha Sipilä Government of Finland 2015: 8)

Experimentation will aim at innovative solutions, improvements in services, the promotion of individual initiative and entrepreneurship... (Programme of the Juha Sipilä Government of Finland 2015: 28)

The entrepreneurial language that is customarily associated with start-up economies is highly visible in the latest government programmes. The programme of the Juha Sipilä's "austerity government" (2015-2019) explicitly articulates that in order to "enhance the funding, equity capital and risk-taking capacity of businesses, the government will implement measures that will impact the needs of start-ups, fast-growth companies, and change-of generation businesses" (Ibid.: 10). In sum, in the formulations of the latest government programmes and their implementation plans, the start-up economy (understood in a broad sense) emerges as a political-economic strategy of the state, as well as a broad cultural political agenda to bring about societal change within and beyond the state apparatus.

The last two elected governments in Finland have built a peculiar link between the future of the nation-state, education, entrepreneurialism, experimentation, (selective) internationalization and innovation. Despite the less visible spatial privileging compared with the case of Milan in Italy (analysed in the following section of this paper), urbanization of state strategies during the years of austerity has been pervasive in Finland. These programmes indeed disclose how regional policies have been increasingly structured around local/regional competences, entrepreneurialism, and technological know-how and predicated on discourses of economic competitiveness since the 1990s. 
For nearly two decades, Finnish innovation policies have privileged major university cities as key nodes of state competitiveness. Even though cities are mentioned only in passing, the strategies of the two latest governments in Finland continue to produce major cities and city-regions (as has been the case in Katainen's government, elected in 2011) as key strategic spaces in the face of global interspatial competition. From the perspective of spatial anchoring of state strategies, it is similarly notable that the latest government seeks to promote a change in the role of cities (and other municipalities) in the future, "from an arranger of services to increasingly a promoter of vitality, entrepreneurship and employment in its area" (Programme of the Juha Sipilä Government of Finland 2015: 32).

Sipilä's current government uses the language of "ecosystems" rather than cities in spatializing innovation based on economic growth. Indeed, the new "Ecosystem forum model" (The Implementation Plan of the Government of Finland 2018: 47) is a telling example of how economic growth at the scale of the state is firmly rooted in urban anchor institutions. This increasingly pervasive urban anchoring of the Finnish state hence occurs in and through economic strategies that highlight the role played by leading universities, as well as research and innovation centres - "expert environments", as Katainen's government (2011: 50) would have it - in the production of the state as a space of wealth, power and belonging.

\section{The statist processes of the start-up economy}

In the ensuing pages, we seek to demonstrate how the state lays the foundations for start-up economic development in various ways, ranging from developing systems of education and regulating state borders, as in the Finnish case, to the cooptation of local elites and powerful media outlets into statedriven urban innovation projects, as the Italian case will document. Politicians and business people talk about the free entrepreneurial culture and the emergence of start-up cities, but neither exists without the state. We also reconsider the role of the state in the production of the entrepreneurial and urban nature of the start-up economy in which the creation of value and wealth tends toward 
"biopolitical production" (Hardt and Negri, 2000: xiii). As affectively intense labour settings, urban societies constitute fertile ground for the biopolitical reconfiguration of knowledge-intensive capitalisms. We suggest that the state occupies a constitutive role in the link between the "urban ground" and entrepreneurial subjectivation.

Both in Finland and Italy, imaginaries of the start-up economy have emerged in the context of austerity politics, which has contributed discursively to the constitution of such an economy as an issue of "national economy". In terms of its actual economic volume, however, the start-up economy has remained minuscule. In 2017, the whole start-up sector attracted 350 million euros in investments in Finland, out of which only 200 million euros were FDI. In Italy the figure was much lower with only 136.6 million euros invested, with a significant portion (about 1/7) of 'innovative' start-ups being located in Milan's metro area. Even in more dynamic Finland, the start-up sector accounts for approximately 2-3 percent of the country's revenue. Irrespective of its modest size as an actually existing economy, the start-up economy represents a form of knowledge-based economization predicated upon two key ideas: extracting value through the invention of an entrepreneurial populace and highlighting the urban anchorage of the national economy.

In Finland, the start-up economy has been promoted by non-state actors such as the Confederation of Finnish Industries (EK), The Federation of Finnish Enterprises, Aalto University, The Central Organization of Finnish Trade Unions (SAK), and the largest cities. These actors constantly seek to mobilize state power to back up and contribute to the emergence of such economy. Moreover, the processes and strategies of the start-up economy include the activities of small political groups and lobbying by business associations, business firms, international organizations and consultant companies who seek to influence the investment decisions and legislative proposals of political actors. As a result, many of the key imaginaries of the start-up economy are currently consolidating and institutionalizing in practices ranging from spatial planning to immigration policies. In this capacity, the imaginaries of the start-up economy penetrate and articulate with or shape other commonsense understandings in society (cf. Mitchell et al., 2003). 
The Finnish government constantly launches policies of digitization and internationalization to respond to the purported needs of the start-up economy. In 2018 alone, the government has launched several major projects to bring about start-up economies in the largest cities. Through the "innovation voucher experiment", the government has sought to "activate a new target group in innovation activities, particularly start-up companies and SMEs" (Government of Finland Implementation Plan 2018: 26). As part of this endeavor, it has issued selective residence permit policies in order to attract high-skilled entrepreneurs from abroad. The Juha Sipilä government has mobilized the publicly funded organization Business Finland to evaluate whether a person who applies for a residence permit fulfills the criteria for a "growth-oriented entrepreneur". Moreover, the government has tailored a project called Talent Boost in which it operates together with the biggest Finnish cities to launch "attractiveness programmes" with the goal of attracting new entrepreneurs and coders to move to Finland (Gustafsson, 2018). These projects have been introduced concomitantly with c. 40 million euros' worth of investment in coder education in Finland. It is notable that both the figure of "coder" and successful businesses in the field of gaming industry have a deep urban connotation in Finland.

In the Finnish context, start-up entrepreneurs are offered particular autonomy, but this autonomy remains firmly bound to the nation-state as a territorial economic unit. It is indeed important to recognize the highly positive and vibrant public images of the start-up economy (and related technologies) that are partly, but importantly, produced and maintained by state agencies, and effectively circulated through media. For instance, the contemporary content is characterized by constant celebration of the super-star entrepreneurs of digital economy (in the context of gaming firms in particular). In the media, these entrepreneurs appear as both globally recognized creative subjects and responsible individuals (and even model taxpayers) who extend and diversify the economic base of the "nation". This "culture of start-up heroes" is one of many aspects in the consolidation and institutionalization of the start-up economy in state-centred processes at time of national revival across the world. 
In the Finnish context, the expansion of the start-up economy is understood by state agencies and policy-makers as having the potential to generate a larger cultural change within the nation-state. Indeed, creative start-up entrepreneurs are often portrayed as if they understand themselves as workers and business subjects in a new manner. The ways in which the start-up subjects relate themselves to work and leisure, for instance, have been debated countless times in national politics and media. The start-up economy thus involves peculiar imaginaries related to new nationaleconomic subject positions, firms that operate with a purpose beyond profit-making, and de-gendered knowledge-intensive forms of capitalism in which women would play an increasingly important role (see e.g. Tolvanen and Pulkkinen, 2018).

What we witness in the Finnish context is an attempt to extend the conceived capacities and orientations of "autonomous start-up entrepreneurs", and the conceived ways in which they live at work and how they live outside of it, to a wider societal fabric through educational system ranging from elementary schools to institutions of higher education. This attempt thus reveals a political will to expand the "class of professionals" as a national survival strategy. In other words, "game-based learning" or courses on entrepreneurialism in elementary schools should not be considered merely technical exercises but rather constitutive elements of the start-up economy. Such educational practices are thus not reflections of the already existing start-up economy; rather, as a form of knowledge-based economization, the start-up economy is constantly being constituted in such practices. In the context of the start-up economy, the technology of subjectivation is associated with the reconstitution of citizen-subjects as human capital and the calculable resources recruited by the state for its operations. In this form of knowledge-based economization, subjectivation refers to the process through which individuals are objectified through educational practices into specific types of economic and political subjects whose characteristics are consistent with contemporary modes of accumulation. Indeed, when asked about the contribution of the state to the emergence of start-up economy in the city of Helsinki, the chief executive of the Ministry of Education responded how 
Innovations do not rise from administrators and political systems... But the state needs to develop entrepreneurialism. The state needs to educate young children to become start-up entrepreneurs, and our political system plays a key role in the economy of innovations. How to educate "new people" is a key question in the context of public power. The politicians did not create the Slush event, but through empowering young people... by de-regulating, the state actually in one way or another created Slush and the emerging start-up scene in Helsinki. In fact, it is the role of public power and policy-making to destroy barriers so that the new economy can develop. In the end, we develop start-up companies for the purposes of large firms which operate in export sector. This is the way to secure tax revenue, and the conditions of decent life in Finland. (Lehikoinen, 2018)

This quote above discloses the operation of the state, which involves public investment in order to bring about technological innovation and change. But more importantly, it involves deep subjectrelated processes that seek to bring about cultural change. In other words, the government seeks to put "the social terrain to work" (Hardt and Negri, 2017: 112), and in so doing to interweave the capitalist mode of production with urban forms of life. In so doing, the start-up state not only becomes a key actor in transforming the commonwealth of urban societies into private property, but also a state that builds and operationalizes a link between the urban, profit, the scale of the individual body and citizenship. It does not come as a revelation, therefore, that the production of autonomous startup entrepreneurs has become firmly entrenched in the national school curricula of Finland.

To illustrate, this process of co-production has been visible in the context of the recent Helsinki city strategy and branding work, which has brought together imaginaries of the city as a digital, economic and social platform, a sort of interactive test-bed, an enabler for urban experiments that also contribute to the growth of the national economy (The City of Helsinki, 2016). These imaginaries have materialized in urban space in various ways, ranging from the development of a start-up "ecosystem" in an old hospital area in the CBD of Helsinki to the strengthening of the image 
of the city as a vibrant place of grass-root happenings. It is important to notice that such local experiments are loudly encouraged within the programme of the contemporary centre-left government enthusiastically with the term "ecosystem" (Programme of the Finnish Government, 2019). In a similar vein with Adkins and Ylöstalo (2018: 160), we hence argue that the Finnish state has promoted urban experimentation in order to foster "innovative solutions, improvements in services, the promotion of individual initiative and entrepreneurship, and the strengthening of regional and local decision-making and cooperation".

The Italian context provides further illustration of the state-orchestrated construction of urban innovation. In a country historically characterized by a highly regionalized pattern of capitalism (Trigilia and Burroni, 2009), this construction exhibits here an inherent tendency towards 'geographical privileging' (Jones, 1997), whereby a few select urban areas and their respective local elites and the media sector are designated to play a pivotal role within economic innovation processes. As we have seen in the previous section, after the successful organization of the World Expo Fair of 2015, Milan has started assuming the role of 'superstar city' (as cities with soaring house prices are called in mainstream urban economics: Gyourko et al., 2013) in the Italian context, attracting an unprecedented wave of international real estate investment during the 2010s. Capitalizing on this mega-event as well as on the recent designation along with Cortina d'Ampezzo (an elitist ski resort in Northeast Italy) as the host city for the 2026 Winter Olympics, Milan has expanded its reputation beyond its traditional role as a globally enticing place for the fashion industry. As a result, today's Milan is increasingly identified as a 'model city' of economic innovation for the entire national political economy, in contrast to Rome, viewed as a deeply dysfunctional national capital. In its foundational stages, Milan's guiding role for the Italian economy was officially embraced at the national government level under Matteo Renzi's leadership and was supported by a broad and loose coalition of Milan-based public and private actors bringing together national and local scales. What distinguishes these actors is a pretension of representing the national level and, at the same time, a 
commitment to explicitly lobbying to enhance the city's reputation as a hub for technology and innovation.

The most significant advocates of Milan's renewed economic centrality include consulting firms, local universities and research institutes, foundations, as well as a set of influential newspapers such as the conservative Corriere della Sera (the newspaper with the highest circulation in Italy, with Chicago-school economists as its leading columnists) and the Sole 24 Ore (a business newspaper owned by Confindustria, the main organization representing private employers in Italy). These news outlets have played a decisive role in propagating the idea of Milan as the city allegedly hosting Italy's only internationally competitive institutions in the technology-oriented higher education sector. The private, elitist Bocconi University (specializing in business and economics and a bastion for neoclassical economic thinking) and the Politecnico of Milan, a state-controlled university institute of technology, have benefitted most from this relentless media campaign. For instance, the digital edition of the Corriere della Sera has a weekly broadcast entitled 'Merito e Regole' (or Merit and Rules), centred on the figure of Roger Abravanel, a business consultant acting as an advocate of 'meritocracy', whose media interventions regularly present Bocconi and Politecnico (despite his conflict of interest, being a member of the advisory board of the latter) as exceptions to the rule of systemic dysfunctions and corruption supposedly affecting Italian universities, particularly those in the South. This view reflects a novel, competitive approach to state funding for public universities that has been advanced by different national governments (despite their political differences) over the last decade.

In 2009, at the time of the centre-right government led by (the Milanese) Silvio Berlusconi, the first competitive funding allocation decided by the newly created National Agency for the Evaluation of the University System (ANVUR) assigned to the Politecnico of Milan a substantial increase in public money, while other universities - especially in the South - saw drastic cutbacks. Apart from some occasional minor corrections, this line of action has persisted over the years. In 2019, under the new 'populist' government in which the (ex-North) League occupies a central 
position, the budget law has allowed the Politecnico of Milan to recruit four times more new academic staff than other major state universities.

Along with its university system (or some parts of it, as Milan's state university has never benefitted from such a media campaign), both Corriere della Sera and Sole 24 have been in the frontline of promoting Milan as the most attractive 'smart city' across the country. Corriere della Sera regularly publicizes the rankings measuring 'smartness' published by the Milan-based Forum PA, an influential consultancy firm specializing in the public administration's ICT-led reorganization processes, which is owned by Digital 360, a for-profit company led by engineering professors of the Politecnico. Since 2015, the year of the Expo and starting point for the governmental strategy on Milan as we have seen above, Milan has always ranked first in the Forum PA's 'ICity Rate', while for the previous three years (the ranking began in 2012) the results were more pluralistic, placing other cities such as Trento and Bologna in the top position. However, the general public found the results of the 2018 Sole 24 Ore's ranking on 'quality of living' far more surprising, as Milan ranked first, based on indicators measuring income per capita and the attractiveness of its housing market, despite being traditionally known at the national level for its record carbon emissions, due to a highly congested car traffic.

The creation of MIND, the Milano Innovation District, in a suburban site previously dedicated to the 2015 Expo fair, is particularly illustrative of the governmental strategy on Milan's national leadership as a hub for high-tech entrepreneurship and the support received from nationally influential, Milan-based media outlets. The District aims to generate an 'innovation ecosystem' centred on Human Technopole (a generously funded research institute in the field of genomics and big data analysis), a public hospital, the science departments of the University of Milan (being relocated from Milan's inner-city area as of 2019), and innovative start-ups as well as third-sector organizations.

The real-estate aspects of the project are dealt with by Arexpo, a company owned by a public partnership comprising Italy's Minister for Economy and Finance, the regional government of 
Lombardy (Milan's region), Milan's municipality, as well as a Foundation specifically dedicated to the transformation of the ex-Expo area. The President of Arexpo is Giovanni Azzone, a Politecnico engineering professor (and previously rector of the same university), who has been also a close collaborator of Forum PA's founders. In September 2016, in appointing Azzone as head of a special agency on natural disasters called Casa Italia (which never became fully operative), then prime minister Matteo Renzi lauded Azzone as one of the best professionals in Italy. Since its beginning, however, the post-Expo project has raised several controversies. Human Technopole has been criticized for being a financially onerous initiative that drains money away from public universities and research institutes. Elena Cattaneo, a pharmacologist recently nominated Senator for life in the Italian legislature in recognition of her outstanding scientific achievements, has repeatedly lamented the opacity of the Human Technopole project, in which the Genoa-based Italian Institute of Technology has taken the lead in the absence of any competitive process. In previous years, this generously funded Institute had been in its turn widely criticized by the Italian scientific community due to its top-down nature and lack of accountability. Moreover, the relocation of university departments from central Milan to the suburban MIND district has prompted a reaction from the local community of students and academic staff, who have taken to the street holding rallies and sit-ins. Finally, start-ups are still far from taking hold, as they tend to favour Milan's inner-city areas, recently re-energized by the arrival of leading technology companies such as Google and Amazon, whose new local offices are both located in the bustling Porta Nuova district. Despite widespread skepticism and many uncertainties at the practical level, Corriere della Sera and Sole 24 Ore are ensuring that the project remains highly visible. In a recently broadcast series (15 October 2018) dedicated to Italy's 'Luoghi dell'Innovazione' (or Places of Innovation), Radio 24 - the Sole 24 Ore's radio channel portrayed the project as follows:

MIND will be a technological and scientific district and a new residential community; it is perhaps the first explicit attempt to recreate in Italy a context similar to key centres for 
technology-intensive innovation at the world level, such as Silicon Valley, the Boston district and Singapore. It is an ambitious project that draws on Milan's main assets - particularly, its prestigious, internationally well-respected universities and the strong business vocation of the surrounding region - with the aim of addressing longstanding demands in this sector, such as the attraction of venture capital, which is at the heart of the Californian model (Radio 24, 2018; author's translation).

Despite the small impact of the start-up economy on the MIND innovation district, the 'capital venture' imaginary is aptly mobilized in support of a project that is still in the process of becoming real (as the previously quoted Radio 24 broadcast briefly admits) and that is contested on different fronts, especially due to its apparently top-down nature. However, Giovanni Azzone firmly objects to this criticism:

We are far from reproducing an Asian model of centralistic developmental state in the field of technological innovation. What we have witnessed and what we have pursued over these two years of institution-building after the Expo is a 'hybrid', bidirectional process involving local actors mobilizing from below that have negotiated their decision-making prerogatives and their actual role within this project with the national government. This latter played a key role in the early, conceptional phase, but it has also learnt from the interaction with Milan's local actors (interview with the author, March 2018).

To recapitulate, what we have learnt from the Finnish and Italian cases is the various ways in which the state can assume a constitutive role in the invention of what is customarily termed as startup economy. As such, the contemporary form of knowledge-intensive capitalism is dependent on nation-states to protect, support, regulate, and extend its "entrepreneurial" and "innovative" processes. The statist production of the start-up economy thus highlights the ways in which the state 
manages and regulates knowledge-intensive capitalism in the interest of "global capital formation" (Hardt and Negri, 2000), and simultaneously re-territorializes political power.

Furthermore, our analysis of Finland and Italy shows how the start-up economy and the reworking of the state are connected. National and local governments not only play a key role in generating processes of "start-up urbanism" for inter-city competition purposes (Rossi and Di Bella, 2017), but they are also re-reworked in these processes. As part of this re-working the relationship between the state and the urban become more intensive than in the previous rounds of economic restructuring; this relocates the urban political forces within the state apparatus and increases their action space. It is for this reason that the building up of the start-up state is characterized by increasing critique towards the previous "statist" economic forms and associated investment patterns. The recent emphasis on the importance of start-ups for national economic success, and the related plans to include more entrepreneurial content in primary school tuition, for instance, must be understood against this backdrop. Similarly, in Italy Luigi Di Maio - the leader of the Five Star Movement, the 'citizen-led' party that has taken the lead in the 'populist' coalition government formed in June 2018 - has in recent times borrowed the idea of the 'smart nation' from Emmanuel Macron and combined it with anti-establishment rhetoric against labour unions. In Luigi Di Maio's intentions, the notion of smart nation implies that the new social power gained by innovative start-ups and online-based professions will compensate for the inevitable loss of jobs in the conventional economy, serving as a glue that holds together Italy's struggling economy (Ciccarelli, 2017).

\section{Conclusion}

We have argued in this paper that the latest phase of knowledge-based economization has become increasingly salient in the imaginaries of start-up economies, disclosing some of the ways in which capitalist societies are witnessing an expansion in the processes of entrepreneurialization and urbanization. In a similar vein with Çalışkan and Callon (2009), we have excavated the state-driven modalities of such economization by focusing on issues such as urban innovation projects, 
educational systems, border policies, and investment schemes in Finland and in Italy and argued that these imaginaries and processes are constitutive of what we have conceptualized as a start-up state. In our perspective, the state is an active agent in the process of transforming the commonwealth of the urban experience into private property in the form of technology-intensive start-up economies. It is also for this reason why we have argued that the entrepreneurial and urban nature of such an economy is produced in state-driven processes that seek to reinvent the state as a national economic territory.

Within the EU, the rise of the start-up economy has to be understood against the backdrop of the post-recession transition of the early 2010s. The start-up economy emerged at a time in which economic and political elites were struggling to leave behind the spectres of 'secular stagnation' and related anxieties within the middle class that had become generalized with the crisis of the Eurozone and the subsequent low-growth performances of national economies.

Within the European Union in the 2010s, two characteristics of the start-up state can be detected. First, in the EU the start-up state has taken form as a byproduct of the age of austerity in the early 2010s. As a post-crisis phenomenon, the start-up state highlights the economic promise of bottom-up entrepreneurial processes. It seeks to enforce the culture of innovation, entrepreneneurialization, internationalization, and risk-taking through various policies ranging from education to borders to urban transformation. Highlighting these policies is relevant and valuable in the context of austerity politics, as they carry the promise of a relatively small price tag. The rise of the start-up economy does not signal the return of the late-Keynesian entrepreneurial state. Neither does it simply denote the process whereby cities functioning as complex and decentred business ecosystems internalize "entrepreneurial logics” (Peck, 2014: 399; cf. Harvey, 1989). Compared with the neo-Keynesian entrepreneurial state, the start-up state is more hesitant to act as an investor or risk-taker. At the same time, it does not limit itself to the merely managerial and coordinating role envisaged by neo-Jacobsian theorizers of self-organized business ecosystems. Instead, the start-up state works through the material and symbolic construction of visible, highly mediatized projects that 
would ideally result in a broad cultural change - entrepreneurialization. It thus operates through indirect political technologies to generate the framework conditions for the entrepreneurial life, and for the associated indirect realization of both private investments and economic value. In this capacity, the start-up state seeks to harness the full potential of human life to the expansion of its economic base.

Second, the start-up state mobilizes urban imaginaries and governmentalities in particular to work towards entrepreneurialization of society, and to carry out economic projects, agendas and planning projects that contribute to the rise of "attractive" start-up economic forms. We therefore argue that, compared with the entrepreneurial state á la Mazzucato (2013), what we term the 'startup state is more anchored to the urban. At the same time, compared with the neo-managerial model of innovation ecosystem theorists, the role of the start-up state appears to be also conceptional and generative, not just coordinative. In other words, the state is not only becoming more experimental in terms of bringing about a broad cultural change in the name of entrepreneurialization, but also in terms of generating economic activities that are infused with an urban mentality for the sake of national economy and competitiveness. We hence underscore that the start-up economy should not be considered as a non-statist and market-driven economic form, that develops solely from the bottom-up activities of skilled 'start-up heroes', their entrepreneurial mentalities, and the actions of private venture capitalists, and that is "freed" from the regulatory practices of the state.

To sum up, by generating entrepreneurial and digital capacities and orientations of the populace through education and other governmental technologies, the state instrumentalizes urban life in the contemporary capitalist conjuncture in the name of "national interest". Our analysis of Finland and Italy demonstrates that by extending the logics, ethics and principles of start-up economy to the wider national fabric, the start-up state not only valorizes urban environments as interactional economic contexts, but also re-articulates national welfare and societal expectations of prosperity in terms of an all-embracing entrepreneurial economy and its associated production of value. Our perspective thus seeks to amend both neo-Keynesian and neo-Jacobsian interpretations of the 
economic governance of technology-based economies: the realities of high-tech start-up economies show a qualitatively transformed role of the state, one which goes beyond conventional boundaries of direct intervention versus coordination role that still tends to polarize public and scholarly debates alike. In this capacity, the historically contingent and geographically variegated trajectories of the start-up state open up a more hybridized view to the recent development of knowledge-intensive capitalism.

Finally, the concept of the start-up state opens the way to a socio-spatial critique of urbanized capitalism. From a critical perspective, the urban space of the start-up economy works as a technology itself: it is intended to break down the barriers between the domains of work, home and leisure, and to function as a production site for the new artisans of knowledge-intensive capitalism. It is indeed the constant search for value and growth that locates the urban at the core of political strategies seeking to connect the territorial state to today's capitalist mode of production founded on the extractive valorization of affects, emotions and subjectivities in the 'platform metropolis' (Rossi, 2019b).

We believe that the persistent imaginary and common sense according to which the start-up economy is almost exclusively produced in the interaction between private economic actors, start-up entrepreneurs and entrepreneurial city governance, harmfully de-politicizes societal development and prevents critical scholars to tailor alternative futures that would re-imagine the role of functions of start-up economies. The dominant imaginary thus effectively ignores not only the role of the state but also the role of the "political" in the context of start-up economies. As a result, particular forms of entrepreneurialism and urbanization are distanced from societal contestation and struggle, and become treated as if they were neutral labels that express spontaneous endogenous dynamics. Critical analysis of the start-up state is therefore needed in order to imagine the institutional and policy changes "required to take us from the insular knowledge economy that we have to the inclusive one that we need" (Unger, 2019: 2). 


\section{References}

Adkins L and Ylöstalo H (2018) Experimental policy, price, and the provocative state. Distinktion: Journal of Social Theory 19, 152-169.

Ahlqvist T and Moisio S (2014). Neoliberalization in a Nordic state: From cartel polity towards a corporate polity in Finland. New Political Economy 19(1), 21-55.

Amin A and Malmberg A (1992) Competing structural and institutional influences on the geography of production in Europe. Environment and Planning A: Economy and Space 24(3): 401-416.

Asheim B, Coenen L and Vang J (2007) Face-to-face, buzz, and knowledge bases: Sociospatial implications for learning, innovation, and innovation policy. Environment and Planning C: Politics and Space 25(5): 655-670.

Barber BR (2013) If Mayors Ruled the World. New Haven: Yale University Press.

Blyth M (2013) Austerity: History of a Dangerous Idea. New York: Oxford University Press.

Bunnell T (2002) Cities for nations? Examining the city-nation-state relation in Information Age Malaysia. International Journal of Urban and Regional Research 26(2): 284-298.

Çalışkan K and Callon M (2009) Economization, part 1: shifting attention from the economy towards processes of economization. Economy and Society 38(3): 369-398.

Castells M and Hall PG (1994) Technopoles of the World: The Making of 21st Century Industrial Complexes. New York: Routledge.

Castells M and Himanen P (2002) The Information Society and the Welfare State: The Finnish Model. Oxford: Oxford University Press.

Ciccarelli R (2017) Luigi 'Smart' Di Maio contro i sindacati: il futuro è una start-up [Luigi 'Smart' Di Maio against labour unions: The future is a start-up]. Il Manifesto 1 October. Available at: https://ilmanifesto.it/luigi-smart-di-maio-contro-i-sindacati-il-futuro-e-una-start-up/

Cohen B and Muñoz P (2016) The Emergence of the Urban Entrepreneurs. How the Growth of Cities and the Sharing Economy Are Driving a New Breed of Innovators. Westport, CT: Praeger. 
The City of Helsinki (2016) Helsinki City Strategy, 2017-2021. Helsinki: The City of Helsinki.

Dahlman CJ, Routti J and Ylä-Anttila P (2006) Finland as Knowledge Economy: Elements of Success and Lessons Learned. Washington, DC: World Bank.

Dierwechter, Y (2018) The smart state as utopian space for urban politics. In: Ward, K, Jonas AEG, Miller B and Wilson D (eds) The Routledge Handbook on Spaces of Urban Politics. London: Routledge, pp. 47-57.

Florida R (2017) The New Urban Crisis: How Our Cities Are Increasing Inequality, Deepening Segregation, and Failing the Middle Class - And What We Can Do About It. New York: Basic Books.

Florida R and Mellander C (2016) Rise of the start-up city: The changing geography of the venture capital financed innovation. California Management Review 59(1): 14-38.

Florida R, Adler P and Mellander C (2017) The city as innovation machine. Regional Studies 51(1): 86-96.

Florida R \& King K M (2018). Urban Start-up Districts: Mapping Venture Capital and Start-up Activity Across ZIP Codes. Economic Development Quarterly 32(2), 99-118.

Glaeser E (2011) Triumph of the City. How Our Greatest Invention Makes Us Richer, Smarter, Greener, Healthier, and Happier. London: MacMillan.

Government of Finland (2019) Programme of Prime Minister Antti Rinne's Government. Inclusive and Competent Finland - A Socially, Economically and Ecologically Sustainable Society. Helsinki: Publications of the Finnish Government 2019:25.

Gustafsson J (2018) Suomesta on tehtävä ohjelmistoalan osaajille maailman paras paikka. [We must make Finland the best place for software professionals]. Helsingin Sanomat 26.10. Available at: https://www.hs.fi/mielipide/art-2000005876549.html

Gyourko J, Mayer C and Sinai T (2013) Superstar cities. American Economic Journal: Economic Policy 5(4): 167-199.

Hardt M and Negri A (2000) Empire. Cambridge, MA: Harvard University Press. 
Hardt M and Negri A (2017) Assembly. New York: Oxford University Press.

Harvey D (1989) From managerialism to entrepreneurialism: The transformation in urban governance in late capitalism. Geografiska Annaler B: Human Geography 71(1): 3-17.

Implementation Plan of the Government of Finland (2018) Finland, a Land of Solutions. Helsinki: The Government of Finland.

Jenkins S (2015) The trials and triumphs of the city: Edward Glaeser in conversation. The Guardian 21.5. Available at: https://www.theguardian.com/cities/2015/may/21/what-are-cities-doing-soright-and-so-wrong-the-experts-go-head-to-head

Jessop B (1990) State Theory. Putting the Capitalist State in Its Place. Cambridge: Polity.

Jones M (1997) Spatial selectivity of the state? The regulationist enigma and local struggles over economic governance. Environment and Planning A: Economy and Space 29(5): 831-864.

Lehikoinen A (2018) Presentation in the Helsinki Symposium 21.3.2018.

Mahizhnan A (1999) Smart cities: The Singapore case. Cities 16(1): 13-18.

Mancini G (2016) Firmato il Patto per Milano. Renzi: 'Città modello di responsabilità [Contract for Milan has been signed. Renzi: 'Model city for responsibility']. Il Sole 24 Ore 13 September. Available at: https://www.ilsole24ore.com/art/impresa-e-territori/2016-09-13/firmato-pattomilano-renzi-citta-modello-responsabilita-123024.shtml?uuid=AD1EdZJB

Mazzucato M (2013) The Entrepreneurial State. Debunking Public vs. Private Sectors Myths. London: Anthem Press.

McNeill D (2016) Governing a city of unicorns: Technology capital and the urban politics of San Francisco. Urban Geography 37(4): 494-513.

McNeill D (2017) Global Cities and Urban Theory. London: SAGE Publications Ltd.

Ministero dello Sviluppo Economico (2012) Restart, Italia! Perché dobbiamo ripartire dall'innovazione, dai giovani, dalla nuova impresa [Restart, Italy! Why we should restart from innovation, young people and new enterprises]. Rome. Available at: 
http://sviluppoeconomico.gov.it/index.php/it/per-i-media/pubblicazioni/2030418-rapportorestart-italia

Mitchell K, Marston S and Katz C (2003) Introduction: Life's work: An introduction, review and critique. Antipode 35(3): 415-442.

Moisio S (2018a) Urbanizing the nation-state: Notes on the geopolitical growth of cities and cityregions. Urban Geography 39(9): 1421-1425.

Moisio S (2018b) Geopolitics of the Knowledge-based Economy. London: Routledge.

Moisio S and Paasi A (2013) From geopolitical to geoeconomic? The changing political rationalities of state space. Geopolitics 18(2): 267-283.

Montgomery C (2013) Happy City. Transforming Our Lives Through Urban Design. New York: Penguin.

Moretti E (2013) The New Geography of Jobs. Boston, MA: Mariner Books.

Moulier Boutang Y (2011) Cognitive Capitalism. Cambridge: Polity.

Negri A (2018) From the Factory to the Metropolis: Essays Volume 2. Cambridge: Polity.

Ong A (2006) Neoliberalism as Exception: Mutations in Citizenship and Sovereignty. Durham, NC: Duke University Press.

Peck J (2014) Entrepreneurial urbanism between uncommon sense and dull compulsion. Geografiska Annaler B: Human Geography 96(4): 396-401.

Peck J (2016) Economic rationality meets celebrity urbanology: Exploring Edward Glaeser's city. International Journal of Urban and Regional Research 40(1): 1-30.

Programme of Prime Minister Jyrki Katainen's Government (2011) Helsinki: The Government of Finland.

Programme of Prime Minister Juha Sipilä's Government (2015) Helsinki: The Government of Finland.

Radio 24 (2018) Luoghi dell'innovazione: MIND - Milano Innovation District [Places of innovation: MIND - $\quad$ Milano Innovation District]. Podcast available at: 
https://www.radio24.ilsole24ore.com/programma/smart-city/luoghi-innovazione-mind-milano124549-gSLAz3HVrC

Read J (2009) A genealogy of homo-economicus: Neoliberalism and the production of subjectivity. Foucault Studies 6(February issue): 25-36.

Rossi U (2017) Cities in Global Capitalism. Cambridge: Polity Press.

Rossi U (2019a) Fake friends: The illusionist revision of Western urbanology at the time of platform capitalism. Urban Studies, online first: DOI 10.1177/0042098018821581.

Rossi U (2019b) The common-seekers: Capturing and reclaiming value in the platform metropolis. Environment and Planning C: Politics and Space, on-line first: DOI 10.1177/2399654419830975.

Rossi U and Di Bella A (2017) Start-up urbanism: New York, Rio de Janeiro and the global urbanization of technology-based economies. Environment and Planning A 49(5): 999-1018.

Smith, PD (2012) Triumph of the City by Edward Glaeser - review. The Guardian 28.2. Available at: https://www.theguardian.com/books/2012/feb/28/triumph-city-edward-glaeser-review

Soja E (1980) The socio-spatial dialectic. Annals of the Association of American Geographers 70(2): $207-225$.

Storper M (1997) The Regional World: Territorial Development in a Global Economy. New York: Guilford Press.

Teittinen P (2015) Tutkija: "Suomi kärsii neutraaliuden harhasta" [Researcher: Finland suffers from the illusion of neutrality]. Helsingin Sanomat 4.6.2015, A29.

Tolvanen J and Pulkkinen M (2018) Isät, rohkaiskaa tyttäriänne kiinnostumaan teknologiasta [Fathers: encourage your daughters to become interested in technology]. Helsingin Sanomat 11.11. C10.

Trigilia C and Burroni L (2009) Italy: rise, decline and restructuring of a regionalized capitalism. Economy and Society 38(4): 630-653.

Unger RM (2019) The Knowledge Economy. Verso: London. 
Visnjic I, Neely A, Cennamo C and Visnjic N (2016) Governing the city: unleashing value from the business ecosystem. California Management Review 59(1): 109-140.

Weber R (2002) Extracting value from the city: Neoliberalism and urban redevelopment. Antipode 34(3): 519-540. 